\title{
The Use of Antibiotics in Cryopreservation of Ram Sperm
}

\author{
Elisangela M Madeira ${ }^{1}$, Karina L Goularte ${ }^{1}$, Jorgea Pradieé ${ }^{1}$, Rafael G Mondadori ${ }^{1}$, \\ Thomaz Lucia, Jr. ${ }^{1}$, Ivan Bianchi ${ }^{1}$, Arnaldo D Vieira ${ }^{1}$ and Fábio P L Leite ${ }^{2}$ \\ ${ }^{1}$ Universidade Federal de Pelotas, Faculdade de Veterinária, ReproPel, Pelotas - RS, Brazil \\ ${ }^{2}$ Universidade Federal de Pelotas, CDTec, Biotecnologia, Caixa, Pelotas - RS, Brazil
}

Correspondence should be addressed to: Fábio P L Leite; fabio@leivasleite.com.br

Received Date: 22 January 2014; Accepted Date: 13 March 2014; Published Date: 23 April 2014

Academic Editor: Manuel Ramón

Copyright ( 2014 Elisangela M Madeira, Karina L Goularte, Jorgea Pradieé, Rafael G Mondadori, Thomaz Lucia, Jr., Ivan Bianchi, Arnaldo D Vieira and Fábio P L Leite. Distributed under Creative Commons CC-BY 3.0

\begin{abstract}
Antibiotics are used in extenders for sperm cryopreservation, however no specific regulation has been established for ram sperm. This study evaluates the effects of antibiotics in ram sperm extenders for bacterial control and its effect on sperm viability. Sperm from five rams was collected, cooled and frozen using extenders with the following antibiotics: 100,000 IU/mL penicillin and $100 \mu \mathrm{g} / \mathrm{mL}$ streptomycin (PES); $500 \mu \mathrm{g} / \mathrm{mL}$ gentamycin, $100 \mu \mathrm{g} / \mathrm{mL}$ tylosin, 300 $\mu \mathrm{g} / \mathrm{mL}$ lincomycin and $600 \mu \mathrm{g} / \mathrm{mL}$ spectinomycin (GTLS); $50 \mu \mathrm{g} / \mathrm{mL}$ ceftiofur sodium (CEF); and $1,000 \mu \mathrm{g} / \mathrm{mL}$ enrofloxacin (ENR). Bacillus sp., Corynebacterium sp., Klebsiella sp. and Staphylococcus sp. were isolated from fresh sperm and perpetual area. For cooled sperm, the antibiotic PES, GTLS and ENR were able to reduce the number of colony forming units per $\mathrm{mL}$ (CFU/mL), however, CEF was inefficient in all tested concentrations. Motility of cooled sperm was reduced when GTLS and ENR were used $(P<0.05)$. For thawed sperm, the number of $\mathrm{CFU} / \mathrm{mL}$ was similar across all treatments $(\mathrm{P}>0.05)$, however, motility was reduced with ENR treatment at doses greater than $50 \%(\mathrm{P}<0.05)$. The antibiogram revealed resistance of Staphylococcus sp. and Klebsiella sp. to the penicillin/streptomycin association and to tylosin. Both PES and GTLS were able to control bacterial growth on cooled sperm. However, attention should be given to the antibiotics added to the extenders, which may impair sperm motility.
\end{abstract}

Keywords: Extender, bacterial control, sperm viability, rams.

\section{Introduction}

The increasing specialization of artificial insemination (AI) programs in sheep production demands that sperm collection and processing centers (SCPC) become adjusted to the requirements of regulatory agencies. The World Organization for
Animal Health (OIE, 2009) recommends the inclusion of antibiotics in extenders used in cryopreservation of sperm, in order to control bacterial contamination. In Brazil, these requirements are clearly defined for SCPCs that process sperm from bulls and water buffalos, but no specific regulation is established for ram sperm. 
The inclusion of antibiotics in extenders is recommended for the control of several microorganisms that can be present in sperm (Bielansky, 2007; Thibier and Guerin 2000). Although opportunistic contaminants generally do not incur an important health risk for the inseminated females, they can affect sperm quality (Yániz et al., 2010). Antibiotic associations capable of controlling potentially pathogenic agents have been determined for bull sperm, having no negative effects on sperm quality (Lorton and Sulivan, 1988; Shin et al., 1988).For ram sperm, the determination of antibiotic associations mainly focused on cooled sperm (Yániz et al., 2010), and demonstrating different levels of antibiotic resistance during preservation of cooled sperm (Yániz et al., 2010; Azwi, 2012). In cryopreserved sperm, agents such as Brucella ovis and Actinobacilus seminis can be controlled by the inclusion of gentamicin or the association of penicillin and streptomycin in extenders (Moustacas et al., 2010). One might consider that bacterial populations and their levels of resistance can vary, and that the efficiency can be affected by extender components (Azwi, 2012). Additionally, the direct effect of antibiotics on sperm viability should also be considered (Lorton et al., 1988; Yániz et al., 2010; Azwi, 2012).

The objectives of this study were to determine the efficiency of antibiotics in controlling bacterial growth on cooled and thawed ram sperm, and their potential effects on sperm viability after cooling and thawing.

\section{Materials and methods}

\section{Sperm Processing and Evaluation}

Five 3-4 years old sexually mature Corriedale rams were used as sperm donors, having the follow sperm characteristics: total sperm motility of at least 70\%; and score (0-5) of sperm vigor equal or greater than 3 . The rams were kept under semi-extensive conditions at the Universidade Federal de Pelotas (UFPel: 3148'17.91"S; and 52²5'4.36"W), having access to native pasture, mineral salt and water ad libitum during the daytime and being fed concentrated supplements twice a day. At night, the rams were housed in barns covered with wood shaving bedding.

Prior to sperm collection, the preputial ostium was cleaned with sterile saline $(0.9 \% \mathrm{NaCl})$ and paper towel. Then, a sample of the preputial content was collected with a swab. Sperm collection was performed using an artificial vagina, twice a week for six weeks. All experimental procedures used in this study were approved by the UFPel Ethics and Animal Experimentation Committee (Registration No. 4383/2010).

Sperm samples were submitted to microbiological evaluation prior to dilution with tris-egg yolk extender (Evans \& Maxwell, 1987). After dilution, samples with $2 \times 10^{9}$ spermatozoa/mL (determined in a Neubauer chamber) were pooled, so each ram contributed equally to the final sperm concentration. Sperm samples were subsequently diluted in an extender containing: $300 \mathrm{mM}$ Tris-hydroxymethylaminomethane; $30 \mathrm{mM}$ fructose; and 94.7 $\mathrm{mM}$ citric acid monohydrate (Evans \& Maxwell, 1987). After that, sperm samples with concentration of $4 \times 10^{8}$ spermatozoa $/ \mathrm{mL}$ were split in the following treatments: Control, with no antibiotics; PES, consisting of 100,000 $\mathrm{IU} / \mathrm{mL}$ penicillin and $100 \mu \mathrm{g} / \mathrm{mL}$ streptomycin (Milli-Q water diluted penicillin $\mathrm{g}$ benzathine and streptomycin sulphate, Sigma Chemical Company, St. Louis, MO, USA) (Salamon and Maxwell. 2000); GTLS, consisting of $500 \mu \mathrm{g} / \mathrm{mL}$ gentamicin (Gentrin, Ourofino Agronegócio, São Paulo, SP, Brazil), 100 $\mu \mathrm{g} / \mathrm{ml}$ tylosin (Tylan 200, Elanco Animal Health, São Paulo, SP, Brazil), $300 \mu \mathrm{g} / \mathrm{mL}$ lincomycin and $600 \mu \mathrm{g} / \mathrm{mL}$ spectinomycin (LincoSpectin, Pfizer Animal Health, São Paulo, SP, Brazil) (Lorton and Sulivan, 1988); CEF, consisting of $50 \mu \mathrm{g} / \mathrm{mL}$ ceftiofur sodium (Excenel, Pfizer Animal Health, São Paulo, SP, Brazil) (Guilmoto and Regault, 1996) and; ENR, consisting of $1000 \mu \mathrm{g} / \mathrm{mL}$ enrofloxacin (Kinetomax, Bayer Animal Health, Rio de Janeiro, Brazil) (Tomczyk and Minta, 2002). All treatments 
were also tested at 50,75, 125 and $150 \%$ of the recommended dose (considered as $100 \%)$. Thus, considering the control, 21 treatments were tested. Glycerol (SigmaAldrich, St. Louis, MO, USA) was added to the extender, at a final concentration of $5 \%$. For each treatment, five $0.25 \mathrm{~mL}$ straws containing $50 \times 10^{6}$ spermatozoa were cooled at $5{ }^{\circ} \mathrm{C}$ for $2 \mathrm{~h}$ and subsequently frozen in vapor of liquid nitrogen (Salamon and Maxwell, 2000). Samples were thawed in water bath at $37^{\circ} . \mathrm{C}$ during $30 \mathrm{~s}$.

Parameters of sperm quality were evaluated after $2 \mathrm{~h}$ of cooling at $5{ }^{\circ} \mathrm{C}$ and also after thawing, keeping the samples incubated in a water bath at $37{ }^{\circ} \mathrm{C}$ for 10 min. Sperm motility was determined with an optical microscope equipped with heating stage at $37^{\circ} \mathrm{C}$ (Olympus BX 51, Sapporo, Japan). Sperm membrane and acrosome integrity were both determined with an epifluorescence microscope (Eclipse 80i, Nikon Instruments Inc., Melville, NY, USA). Carboxifluorescein diacetate and propidium iodide (SigmaAldrich, St. Louis, MO, USA) were used to evaluate membrane integrity (Harrison and Vickers, 1990), whereas propidium iodide and lectin from Arachis hypogaea conjugate (Sigma-Aldrich, St. Louis, MO, USA) were used to evaluate acrosome integrity (Kawamoto et al., 1999).

\section{Microbiological Evaluation and Antibiogram}

Microbiological evaluation was done to determine the bacteria present in samples from the preputial ostium, in the extender with no antibiotics and in fresh, cooled and thawed sperm. The samples (swabs) were streaked onto agar with $5 \%$ sheep blood and incubated at $37{ }^{\circ} \mathrm{C}$ in aerobiosis for 48 h. After incubation, the colonies were visualized and a Gram stain performed (Maza et al., 2004). The different types of colonies were isolated and incubated for 24 $\mathrm{h}$ in $10 \mathrm{~mL}$ tubes with Brain Heart Infusion (BHI) medium (Acumedia, São Paulo, SP, Brazil). Then, the culture were spread in the surface of the culture media with a Drigalski loop in the Petri plates containing the following media Brain Heart Infusion Agar (BHI, Acumedia $®)$, Chapman
(Acumedia ${ }^{\circledR}$ ) and MacConkey (Acumedia $($ ), in duplicate, respectively. The plates were incubated at $37^{\circ} \mathrm{C}$ for 24 h. Then bacteria growth (colony forming units, CFU/mL) counting was carried out. To evaluate the total bacteria numbers we consider the growth that was record in BHI, for Staphylococci the growth in Chapman, and for Enterobacteriaceae the growth in MacConkey media. The cultures were submitted to carbohydrate battery and Gram stain, respectively (Carter, 1988).

The number of CFU/mL was quantified in sperm samples collected at the end of the cooling period and after freezing-thawing. A $100 \mu \mathrm{L}$ aliquot of diluted sperm was streaked onto BHI agar with $5 \%$ sheep blood and incubated at $37{ }^{\circ} \mathrm{C}$ for $48 \mathrm{~h}$, as described above.

An antibiogram was performed using autoclave-sterilized paper filter disks impregnated with $2 \mu \mathrm{L}$ of the tested antibiotics (CLSI, 2009). The antibiotic concentrations in the disks were: $10 \mu \mathrm{g}$ penicillin and $40 \mu \mathrm{g}$ streptomycin; $88 \mu \mathrm{g}$ gentamicin; $\quad 40 \mu \mathrm{g}$ tylosin; $100 \mu \mathrm{g}$ lincomycin and $200 \mu \mathrm{g}$ spectinomycin; $100 \mu \mathrm{g}$ ceftiofur sodium; and $200 \mu \mathrm{g}$ enrofloxacin. The disks were distributed in Mueller-Hinton agar plates (Acumedia) previously streaked with the isolated colonies. Plates were kept in an incubator at $37{ }^{\circ} \mathrm{C}$ for $24 \mathrm{~h}$ and the inhibition halos were measured (CLSI, 2009).

\section{Statistical Analysis}

The Shapiro-Wilk test indicated that no responses of interest followed normal distributions. Therefore, sperm motility and integrity of sperm membrane and acrosome were transformed to the arcsine scale, and the number of $\mathrm{CFU} / \mathrm{mL}$ was transformed to the logarithmic scale. All parameters were compared across treatments by analysis of variance, with comparisons of means by Tukey's test. The results referring to parameters of sperm quality were reported in their original scale for the sake of interpretation. All statistical analyses were conducted with (Statistix ${ }^{\circledR}$, 2009). 


\section{Results}

For fresh sperm, motility was $80.3 \pm 1.1 \%$, membrane integrity was $56.8 \pm 6.5 \%$ and acrosome integrity was $76.6 \pm 23.9 \%$. After cooling at $5{ }^{\circ} \mathrm{C}$ for $2 \mathrm{~h}$, motility was $70.9 \pm$ $3.0 \%$, membrane integrity was $69.5 \pm$ $1.7 \%$ and acrosome integrity was $82.5 \pm$ $2.3 \%$. Membrane and acrosome integrity did not differ across treatments $(\mathrm{P}>0.05)$ for cooled sperm. However, even though motility of cooled sperm was generally similar among treatments, it was lower for $150 \%$ GTLS and for ENR at both $125 \%$ and $150 \%(\mathrm{P}<0.05)$ than for the control group (Table 1). For cooled sperm, no difference in $\mathrm{CFU} / \mathrm{mL}$ was observed among the treatments with PES, ENR and GTLS $(\mathrm{P}>0.05)$, with concentrations range between $50-125 \%$. However, at 150\%, all three showed a reduced $\mathrm{CFU} / \mathrm{mL}$ compared with the others concentrations and control (Table 1). No difference in $\mathrm{CFU} / \mathrm{mL}$ was observed for $\mathrm{CEF}(\mathrm{P}>0.05)$, among the tested concentrations.
After thawing, sperm motility was $33.4 \pm$ $2.3 \%$, membrane integrity was $18.2 \pm 1.1 \%$ and acrosome integrity was $73.5 \pm 2.3 \%$. Sperm motility for PES, GTLS and CEF was similar $(\mathrm{P}>0.05)$ to that of the control group (Table 1). However, with ENR at doses greater than $0.5 \mu \mathrm{g} / \mathrm{mL}$, sperm motility was reduced as compared to the control group $(\mathrm{P}<0.05)$. After thawing, the integrity of sperm membrane and acrosome, and the number of $\mathrm{CFU} / \mathrm{mL}$ did not differ among treatments $(\mathrm{P}<0.05)$.

Genera such as, Staphylococcus sp., Klebsiella sp., Corynebacterium sp. and Bacillus sp. were identified in samples from fresh sperm and preputial ostium. Bacterial growth was not significant (less than 30 $\mathrm{CFU} / \mathrm{mL}$ ) in samples of extenders without antibiotics. In the antibiogram, Staphylococcus sp. and Klebsiella sp. presented resistance to tylosin and to the penicillin and streptomycin association.

Table 1: Motility and Colony Forming Units (CFU)/mL x $10^{3}$ of Cooled and Thawed Ram Sperm with and without Inclusion of Antibiotics in the Cryopreservation Extender

\begin{tabular}{|c|c|c|c|c|c|}
\hline \multicolumn{2}{|c|}{ Treatment } & \multicolumn{2}{|c|}{ Sperm motility (\%) } & \multicolumn{2}{|c|}{$\mathrm{CFU} / \mathrm{mL}$} \\
\hline Antibiotic & Dose $(\%)^{*}$ & Cooled & Thawed & Cooled & Thawed \\
\hline Control & 0 & $80.0^{a}$ & $39.2^{\mathrm{ab}}$ & $3.4^{\mathrm{a}}$ & 1.4 \\
\hline \multirow[t]{5}{*}{ PES } & 50 & $74.0^{\mathrm{abc}}$ & $41.2^{\mathrm{a}}$ & $2.8^{\text {abcde }}$ & 1.3 \\
\hline & 75 & $80.0^{a}$ & $40.6^{a}$ & $2.8^{\text {abcdef }}$ & 1.2 \\
\hline & 100 & $64.0^{\mathrm{bc}}$ & $42.0^{\mathrm{a}}$ & $2.2^{\text {abcdefgh }}$ & 1.6 \\
\hline & 125 & $66.0^{\mathrm{abc}}$ & $39.4^{\mathrm{ab}}$ & 2.7abcdef & 1.3 \\
\hline & 150 & $76.0^{\mathrm{ab}}$ & $35.0^{\mathrm{abcd}}$ & $1.7 \mathrm{bcdefgh}$ & 1.3 \\
\hline \multirow[t]{5}{*}{ GTLS } & 50 & $76.0^{\mathrm{ab}}$ & $40.4^{a}$ & $1.6^{\text {cdefgh }}$ & 1.1 \\
\hline & 75 & $76.0^{\mathrm{ab}}$ & $33.2^{\mathrm{abcd}}$ & $1.6^{\text {cdefgh }}$ & 1.2 \\
\hline & 100 & $74.0^{\mathrm{abc}}$ & $37.8^{\mathrm{abc}}$ & $1.5^{\text {fgh }}$ & 1.0 \\
\hline & 125 & $68.0^{\mathrm{abc}}$ & $32.2^{\mathrm{abcd}}$ & $1.5^{\text {efgh }}$ & 1.3 \\
\hline & 150 & $62.0^{\mathrm{bc}}$ & $33.4^{\mathrm{abcd}}$ & $1.3^{\mathrm{h}}$ & 0.9 \\
\hline \multirow[t]{5}{*}{ CEF } & 50 & $80.0^{\mathrm{a}}$ & $40.2^{\mathrm{a}}$ & $2.9 \mathrm{abcd}$ & 0.8 \\
\hline & 75 & $76.0^{\mathrm{ab}}$ & $40.4^{\mathrm{a}}$ & 2.7abcdef & 0.8 \\
\hline & 100 & $70.0^{\mathrm{abc}}$ & $39.2^{\mathrm{ab}}$ & $3.0^{\mathrm{ab}}$ & 1.2 \\
\hline & 125 & $70.0^{\mathrm{abc}}$ & $34.4^{\mathrm{abcd}}$ & $2.9 \mathrm{abc}$ & 0.9 \\
\hline & 150 & $70.0^{\mathrm{abc}}$ & $35.6^{\mathrm{abcd}}$ & 2.7 abcdefg & 0.9 \\
\hline \multirow[t]{5}{*}{ ENR } & 50 & $68.0^{a b c}$ & $31.0^{\text {abcd }}$ & $1.8^{\text {bcdefgh }}$ & 1.4 \\
\hline & 75 & 68.0 $0^{\mathrm{abc}}$ & $27.6^{\text {bcde }}$ & $1.5^{\text {efgh }}$ & 1.0 \\
\hline & 100 & $70.0^{\mathrm{abc}}$ & $26.6^{\text {cde }}$ & $1.4^{\mathrm{h}}$ & 1.2 \\
\hline & 125 & $62.0^{\mathrm{bc}}$ & $24.6^{\text {de }}$ & $1.4 \mathrm{gh}$ & 0.8 \\
\hline & 150 & $60.0^{c}$ & $18.6^{\mathrm{e}}$ & $1.6^{\text {defgh }}$ & 0.9 \\
\hline SEM & & \pm 2.9 & \pm 2.4 & \pm 0.2 & \pm 0.3 \\
\hline
\end{tabular}

a,b,c,d,e,f,g,hMeans \pm SEM (in logarithmic scale) differ across treatments $(\mathrm{P}<0.05)$.

*PES = 100,000 IU $/ \mathrm{ml}$ penicillin and $100 \mu \mathrm{g} / \mathrm{ml}$ streptomycin; GTLS: $500 \mu \mathrm{g} / \mathrm{ml}$ gentamicin; $100 \mu \mathrm{g} / \mathrm{ml}$ tylosin; 300 $\mu \mathrm{g} / \mathrm{ml}$ lincomycin and $600 \mu \mathrm{g} / \mathrm{ml}$ spectinomycin; CEF: $50 \mu \mathrm{g} / \mathrm{ml}$ ceftiofur sodium; ENR: 1,000 $\mu \mathrm{g} / \mathrm{ml}$ enrofloxacin. 


\section{Discussion}

To our knowledge this is the first study that evaluated the effects of the addition of ENR and CET in extenders for ram sperm cryopreservation, along with other antibiotics, on sperm viability and bacterial counts. The microorganisms isolated in this study were usually isolated from the environment (Klebsiella sp., Corinebacterium sp., Bacillus sp. and Staphilococcus sp.), being the latter among the most common bacterial isolated from rams (Yániz et al., 2010).

The numbers of $\mathrm{CFU} / \mathrm{mL}$ observed in samples from the preputial ostium and from fresh sperm were both lower than the levels recommended by the World Organization for Animal Health (OIE, 2009). However, the sperm dilution effect might play a role in the $\mathrm{CFU} / \mathrm{mL}$ observed in fresh sperm, since sperm concentration is greater for rams than for bulls. Nevertheless, the hygiene conditions during sperm collection in the present study may be considered at most satisfactory, if compared with commercial SCPCs. Thus, our results suggest that ram sperm can be frozen without inclusion of antibiotics in the extender, since the freezing-thawing process by itself can reduce the bacterial population up to levels accepted by international regulatory agencies.

The antibiogram identified resistance of Staphylococcus sp. and Klebsiella sp. to the penicillin and streptomycin association and to tylosin. Despite that, tylosin contributed to inhibiting bacterial growth in cooled sperm, when associated with other antibiotics. The association of penicillin and streptomycin was effective in controlling bacterial growth in cooled sperm only at its greatest concentration. This finding reinforces the fact that there is bacterial resistance to that antibiotic association at commonly used doses. However, the post-thawing number of $\mathrm{CFU} / \mathrm{mL}$ in ram sperm was similar among treatments with and without inclusion of antibiotics, regardless of the dose. The reduction in $\mathrm{CFU} / \mathrm{mL}$ observed in the control treatment without antibiotics is likely to be a consequence of freezing sperm using an extender with 5\% glycerol, since bacteria are usually cryopreserved with glycerol concentrations exceeding 15\% (Hubálek, 2003). Reduction in the number of $\mathrm{CFU} / \mathrm{mL}$ attributed to freezing was also reported with the use of $10 \%$ dimethyl sulfoxide as cryoprotectant (Kipp et al., 2004). So, it may be suggested that the reduction in $\mathrm{CFU} / \mathrm{mL}$ is due to the freezing-thawing process.

The inclusion of antibiotics in extenders at the tested concentrations did not influence the integrity of either sperm membrane or acrosome, in both cooled and thawed sperm. Nevertheless, sperm motility was negatively affected with antibiotic addition. $100,000 \mathrm{IU} / \mathrm{mL}$ and $100 \mu \mathrm{g} / \mathrm{mL} \mathrm{PES}$, $750 \mu \mathrm{g} / \mathrm{mL}, \quad 150 \mu \mathrm{g} / \mathrm{mL}, \quad 450 \mu \mathrm{g} / \mathrm{mL}$ and $900 \mu \mathrm{g} / \mathrm{mL}$ GTLS and ENR at both $1,250 \mu \mathrm{g} / \mathrm{mL}$ and $1,500 \mu \mathrm{g} / \mathrm{mL}$ presented sperm motility lower than the control group and also lower than that in treatments with $75,000 \mathrm{IU} / \mathrm{mL}$ and 75 $\mu \mathrm{g} / \mathrm{mL}$ PES and $25 \mu \mathrm{g} / \mathrm{mL}$ CEF. For frozenthawed sperm, most treatments presented similar motility, except those where ENR was included at doses exceeding $0,500 \mu \mathrm{g} / \mathrm{mL}$, which reduced sperm motility. Although the present study was the first to report direct effects of ENR in the viability of cryopreserved ram sperm, other studies reported reduction in sperm motility for other species, related to impairment of spermatogenesis due to parenteral application of ENR (Aral et al., 2008; Sinha et al., 2012).

In the present study, the reduction in sperm motility may be attributed to the reduction of mitochondrial activity in spermatozoa, since quinolone antibiotics inhibit DNA gyrase (Sárközy, 2001). This particular mechanism of action allows the elimination of strains resistant to antibiotics which act on the cell wall, the cytoplasmic membrane or on protein synthesis. The development of resistance to their use was only observed under experimental conditions, after repeated passages, appearing in a slow and gradual manner (Scheer, 1987b). 


\section{Conclusions}

Bacterial growth can be reduced in cooled ram sperm with inclusion of antibiotic associations of penicillin and streptomycin, and of gentamicin, tylosin, lincomycin and spectinomycin in the extender, but not with sodium ceftiofur. The inclusion of antibiotics in extenders for frozen ram sperm may not be necessary, when using healthy sperm donors under satisfactory hygiene conditions. The freezing process may keep sperm contamination within the levels recommended by regulatory health agencies. The use of enrofloxacin should be avoided due to negative effects on sperm motility.

\section{Acknowledgements}

This research was funded with a scholarship given to the first author by CAPES and with a research grant \# 578597/2008-0 from MCT/CNPq/MAPA/SDA.

\section{References}

Aral, F., Karaçal, F. \& Baba, F. (2008). "The Effect of Enroflocacin on Sperm Quality in Male Mice," Research in Veterinary Science (84) 95-99.

Azawi, O. I. \& Ismaeel, M. A. (2012). "Influence of Addition of Different Antibiotics in Semen Diluent on Viable Bacterial Count and Spermatozoal Viability of Awassi Ram Semen," Veterinary World (5) 75-79.

Bielanski, A. (2007). "Disinfection Procedures for Controlling Microorganisms in the Semen and Embryos of Humans and Farm Animals," Theriogenology (68) 1-22.

Carter, G. R. (1988). 'Essentials of Veterinary Bacteriology and Mycology,' 1st Ed. Ed. Roca Ltda, São Paulo, SP, Brazil.

CLSI. (2009). Clinical and Laboratory Standards Institute. 'Performance Standards for Antimicrobial Disk Susceptibility Tests; Approved Standard,' 10th Ed., Wayne, PE, USA. de la Maza, L. M., Pezzlo, M. T., Shigei, J.T. \& Peterson, E. M. (2004). 'Color atlas of Diagnostic Microbiology,' ASM Press, Washington D.C., USA.

Evans, G. \& Maxwell, W. M. C. (1987). 'Salamon's Artificial Insemination of Sheep and Goats,' Star Printery Pty Ltd, Australia.

Guilmoto, H. \& Regault, M. (1996). 'Use of Ceftiofur in Boar Semen Diluents,' Conference Proceeding of International Pig Veterinary Society Congress 14 (1996) 138.

Harrison, R. A. P. \& Vickers, S. E. (1990). "Use Fluorescent Probes to Assess Membrane Integrity in Mammalian Spermatozoa," Journal of Reproduction and Fertility (88) 343-352.

Hubálek, Z. (2003). "Protectants Used in Cryopreservation of Microorganisms," Cryobiology (46) 205-229.

Kawamoto, A., Ohashi, K., Kishikawa, H., Zhu, L.- Q., Azuma, C. \& Murata, Y. (1999). "Two-Color Fluorescence Staining of Lectin and Anti-CD46 Antibody to Assess Acrosomal Status," Fertility and Sterility (71) 497-501.

Kipp, F., Linnemann, E., Fisher, R. J., Sibrowski, W. \& Cassens, U. (2004). "Cryopreservation Reduces the Concentration of Detectable Bacteria in Contaminated Peripheral Blood Progenitor Products," Transfusion (44) 1098-1103.

Lorton, S. P., Sullivan, J. J., Bean, B., Kaproth, M., Kellgren, H. \& Marshall, C. (1988). “A New Antibiotic Combination for Bovine Semen," Theriogenology (29) 593-614.

Moustacas, V. S., Xavier, M. N., Carvalho Junior, C. A., Costa, E. A., Henry, M. \& Santos, R. L. (2010). "Effect of Extender Supplementation with Various Antimicrobial Agents on Viability of Brucella Ovis and Actinobacillus Seminis in Cryopreserved Ovine Semen," Theriogenology (74) 1476-1481.

OIE. (2008). World Organization for Animal Health. Manual of Diagnostic Tests and Vaccines for Terrestrial Animals, 6th Ed 
Salamon, S. \& Maxwell, W. M. C. (2000). "Storage of Ram Semen," Animal Reproduction Science (62) 77-111.

Sárközy, G. (2001)." Quinolones: A Class of Antimicrobial Agents," Veterinarni Medicina (46) 257-274.

Shin, S. J., Lein, D. H., Patten, V. H. \& Ruhnke, H. L. (1988). “A New Antibiotic Combination for Frozen Bovine Semen I. Control of Mycoplasmas, Ureaplasmas, Campylobacter Fetus Ssp. Venerealis and Haemophilus Somnus in Frozen Bovine Semen," Theriogenology (29) 577-591.

Sinha, C., Yadav, S., Yadav, B. \& Singh, K. (2012). "Effects of Enrofloxacin Administration on Semen Quality of Barbari Bucks," Journal of Advanced Veterinary Research (2) 179-183.
Thibier, M. \& Guerin, B. (2000). "Hygienic Aspects of Storage and Use of Semen for Artificial Insemination," Animal Reproduction Science (62) 233-251.

Tomczyk, G. \& Minta, Z. (2002). "Elimination of Mycoplasma from the Turkey Semen," Bulletin of the Veterinary Institute in Puławy (46) 11-15.

Yániz, J. L., Marco-Aguado, M. A., Mateos, J. A. \& Santolaria, P. (2010). "Bacterial Contamination of Ram Semen, Antibiotic Sensitivities and Effects on Sperm Quality during Storage at $15^{\circ} \mathrm{C}$," Animal Reproduction Science (122) 142-149. 